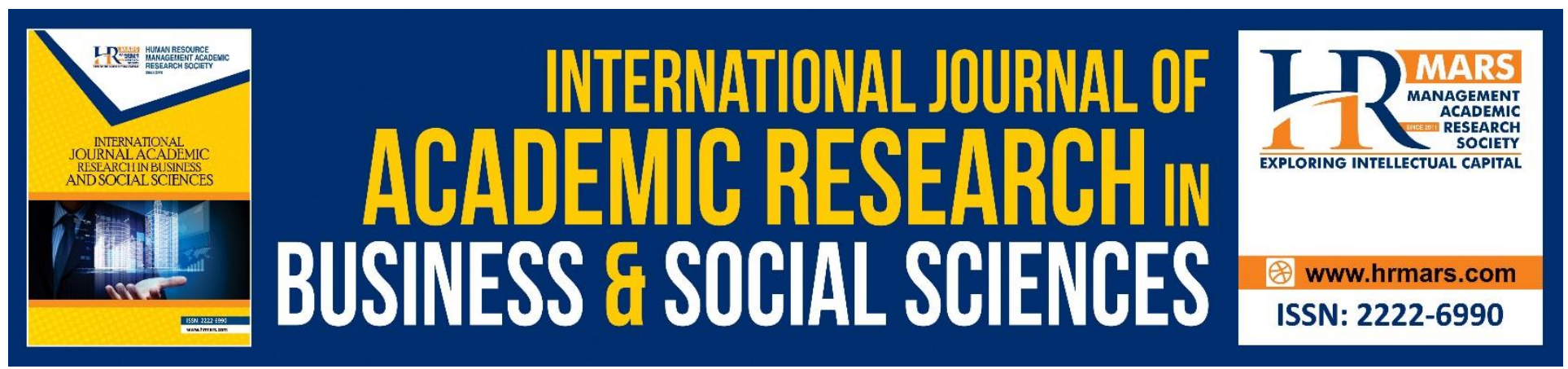

\title{
Factors Influencing Online Purchase Intention among University Students
}

Nurul Nadia Abd Aziz, Normilia Abd Wahid

To Link this Article: http://dx.doi.org/10.6007/IJARBSS/v8-i7/4413

DOI: $\quad 10.6007 /$ IJARBSS/v8-i7/4413

Received: 24 May 2018, Revised: 19 June 2018, Accepted: 28 July 2018

Published Online: 30 July 2018

In-Text Citation: (Aziz \& Wahid, 2018)

To Cite this Article: Aziz, N. N. A., \& Wahid, N. A. (2018). Factors Influencing Online Purchase Intention among University Students. International Journal of Academic Research in Business and Social Sciences, 8(7), 702717.

Copyright: (c) 2018 The Author(s)

Published by Human Resource Management Academic Research Society (www.hrmars.com)

This article is published under the Creative Commons Attribution (CC BY 4.0) license. Anyone may reproduce, distribute, translate and create derivative works of this article (for both commercial and non-commercial purposes), subject to full attribution to the original publication and authors. The full terms of this license may be seen

at: http://creativecommons.org/licences/by/4.0/legalcode

Vol. 8, No. 7, July 2018, Pg. 702 - 717

http://hrmars.com/index.php/pages/detail/IJARBSS

JOURNAL HOMEPAGE

Full Terms \& Conditions of access and use can be found at http://hrmars.com/index.php/pages/detail/publication-ethics 


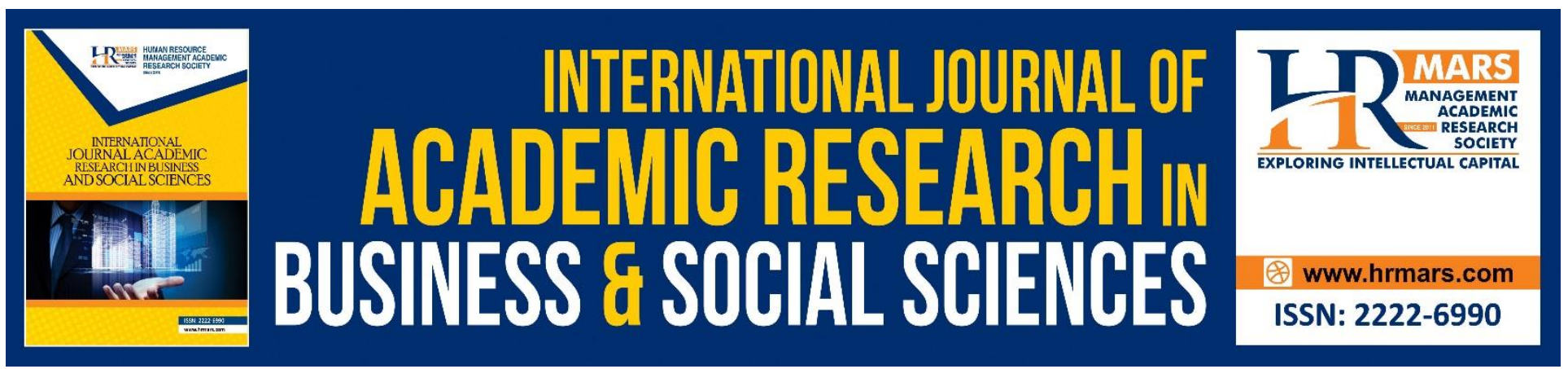

\title{
Factors Influencing Online Purchase Intention among University Students
}

\author{
Nurul Nadia Abd Aziz, Normilia Abd Wahid \\ Faculty of Business and Management, Universiti Teknologi MARA Cawangan Pahang, Malaysia
}

\begin{abstract}
This study focused, through multiple regressions, on the factors that influence online purchase intention among Malaysian university students. The primary data collection method utilises a questionnaire that was developed and distributed based on a systematic sample of 400 students in a higher educational institution in Malaysia. The findings were analysed using Structural Equation Modelling (AMOS) to test the hypotheses. According to the study's results, perceived benefits and perceived ease of use may act as complete mediators since the direct effect of past experience on online purchase intention is no longer significant after the mediators enter the model. This result indicates that past experience affects on perceived benefits and perceived ease of use while these perceptions affects online purchase intention. It was thus recommended that online retailers should maximize their efforts in reinforcing their relationship with the customers including to constantly engage with those that are online.
\end{abstract}

Keywords: Online Purchase Intention; Past Experience; Perceived Benefits; Perceived Ease of Use, University Students

\section{Introduction}

University students who are partially represented by the Gen Y (the Millennials) and Gen Z nowadays have become important shopper segments as most of them are Internet savvies with high computer literacy (Aldhmour \& Sarayrah, 2016; Lissitsa \& Kol, 2016). This group is also influenced by their parents' spending patterns while potentially developing their own spending habits in the future (Handa \& Gupta, 2014). It is vital for online retailers to understand the behaviour of this market segment so that they can execute marketing strategies accordingly (Huseynov \& Yildirim, 2016).

According to statistics by the PayPal payment gateway that handles payment transactions, online purchases have increased three-fold from 2010 to 2015, where the total value of sales in Malaysia surged from RM1.82 billion to RM5.76 billion (Saidi, 2016). These statistics include the total expenditure among university students who are mostly not have a fixed income yet. Some researchers confirmed that the online shopping behaviour is influenced by income (Al-Debei, Akroush, \& Ashouri, 2015; Dhanapal, Vashu, \& Subramaniam, 2015; Gong, Stump, \& Maddox, 2013; Lissitsa \& Kol, 2016). These aforementioned researchers found that consumers with higher incomes tend to purchase through online more compared to lower income consumers. 
INTERNATIONAL JOURNAL OF ACADEMIC RESEARCH IN BUSINESS AND SOCIAL SCIENCES Vol. 8, No. 7, July 2018, E-ISSN: 2222-6990 @ 2018 HRMARS

However, most researches on online shopping behaviour that involve university students (Aldhmour \& Sarayrah, 2016; Faqih, 2016; Ha \& Janda, 2014; Jadhav \& Khanna, 2016; Lian \& Yen, 2014) do not discuss their online shopping behaviour along side the income constraints that they usually face. Since a smart shopper should do a cost-benefit analysis before making a decision to shop online (Chakraborty, Lee, Bagchi-Sen, Upadhyaya, \& Raghav Rao, 2016), it then becomes a question of how university students can engage with online shopping as most of them rely on educational loans and pocket money from their parents (Aziz \& Wahid, 2017). Thus, this study aims to examine the factors that influence online purchase intention in the context of Malaysian university students.

Many studies including those by Al-Debei et al. (2015), Lim, Osman, Salahuddin, Romle \& Abdullah (2016), Salehi, Nwaizugbo \& Ifeanyichukwu (2011), as well as Sheikh, Abbas \& Mehmood (2015) found that there is a significant relationship between past experience (PE), perceived ease of use (PEU) and perceived benefits (PB) with online purchase intention (OPI). However, there is very limited number study that discusses about the function of perceived ease of use and perceived benefits as mediators in the relationship between past experience and online purchase intention, specifically among Malaysian youths. Therefore, this study attempts to measure the relationship between these variables from the context of university students. It is hoped that this study will allow researchers to close the information gap and benefit from the potential appreciation of the presence of university students as an important market segment for online vendors.

\section{Literature Review}

Online shopping is a form of electronic commerce that enables consumers to purchase goods or services directly from retailers via the Internet using a web browser (Aldhmour \& Sarayrah, 2016). Online shopping provides shoppers with the most convenient method purchase just about everything on their wish list without having to rush to physical stores. In fact, the use of this method prevents additional costs such as transportation (including fuel, tolls and parking) while also provide convenience by not having to queue when paying or go through a throng of crowds. With just a click of a mouse button, the customer's desired item will be sent to his/her doorstep with only a minimum charge or some with even free shipping. Occasionally, there are some online retailers who offer free shipping of products and also cash-on-delivery facility (Kumar, 2016). Online purchase intention tends to have a positive relationship with the actual online purchase behaviour (Lim et al., 2016). Thus, the stronger the online purchase intention of an individual, the more likely $\mathrm{s} / \mathrm{he}$ is to perform the online purchase behaviour. Accordingly, we have focused on investigating the factors that influence consumer intention to purchase online as a determinant of actual behaviour.

This study is underpinned by the Technology Acceptance Model (TAM). Davis (1989) proposed the TAM model to predict the use and acceptance of information systems and technology by individual users (Surendran, 2012). Two important factors, which are the perceived usefulness and perceived ease of use are proposed to explain technology usage behaviour (Alomary \& Woollard, 2015). TAM is an adoption of the Theory of Reasoned Action (TRA) and has advanced to become a key model in understanding predictors of human behaviour toward potential acceptance or rejection of the technology (Durodolu, 2016). It is an important theoretical contribution which suggests that when a new technology is introduced to potential users, beliefs on the usefulness and ease of use are essential to determine consumers' attitudes towards the use of technology (Gianina \& Lala, 2014). In short, the TAM model explains that consumer behaviour towards online shopping using new 
INTERNATIONAL JOURNAL OF ACADEMIC RESEARCH IN BUSINESS AND SOCIAL SCIENCES Vol. 8, No. 7, July 2018, E-ISSN: 2222-6990 @ 2018 HRMARS

technology (via Internet) is influenced by their perceptions of usefulness and ease of use that can be experienced through the said technology.

Most previous studies used the term "perceived usefulness" which refers to the advantages associated with online shopping experience such as convenience, price comparison, enjoyment and enhanced customer-retailer relationship (Martin, Mortimer \& Andrews, 2015). Meanwhile, perceived ease of use refers to "the degree to which a person believes that using a particular system would be free from effort" (Davis, 1989). This current study; however, used the term "perceived benefits" which refers to the advantages of searching for information online before making an online purchase (Huseynov \& Yildirim, 2016). Some researchers found that perceived benefit is an important criterion for consumers when they select online stores and may positively influence consumers' online purchase intention (Aldhmour \& Sarayrah, 2016; Lim et al., 2016; Pantano \& Viassone, 2015; Sheikh et al., 2015). In other words, if the consumer has access to all relevant information before purchasing, it will result in higher consumer satisfaction (Massad \& Berardelli, 2016). Since perceived usefulness was found to have a significant relationship to the online purchase behaviour, this study therefore anticipates that perceived benefits of searching and perceived ease of use may also affect online purchase intention.

In addition to perceived ease of use and perceived benefits, past experiences with online shopping are found to be positively correlated with the likelihood of consumers to purchase online. Researchers such as Weisberg, Te'eni \& Arman (2011) found that people with past online purchasing experiences have higher intention to repurchase in the future compared to those without. It implies any consumers who had already bought their desired items online in the past may have more favourable attitude towards online shopping (Chaudary, Ahmed, Gill \& Rizwan, 2014; Nwaizugbo \& Ifeanyichukwu, 2016).

Additionally, some researchers including Hernandez-Ortega, Jimenez-Martinez \& MartinDeHoyos (2008) highlighted that there are significant differences between groups (potential shoppers, new shoppers, and experienced shoppers) on their perception of usefulness and ease of use. They found that the average value of perceived usefulness and perceived ease of use for the sample of experienced shoppers is higher than the other two groups (potential shoppers and new shoppers). Their results indicated that the consumers' experience acquired in the past will last longer and will remain in the consumers' mindset (Jaafar, Lalp \& Mohamed, 2013). When consumers buy products, they evaluate the product which will then result in valuable purchase experience. This experience, in turn, may affect the intention and the decision to repurchase in the future.

Thus, our study proposes and tests two important key factors from the TAM model which are perceived benefits and perceived ease of use to examine the factors influencing online purchase intention among Malaysian youths. The choice for using TAM as a research model to explain Malaysian youth online purchase intention will present strategic implications and directions for the development of online shopping in Malaysia.

Although previous studies demonstrate that past experience may affect online purchase intention, the link between past experience and online purchase intention among Malaysian youths was found to be rare. Moreover, the empirical research that determines the relationship of past experience and online purchase intention with the perceived benefits and perceived ease of use is unclear. Based on the above discussion, in this study, it is essential to formulate the following hypotheses:

H1: Past experience has a significant effect on online purchase intention. 
INTERNATIONAL JOURNAL OF ACADEMIC RESEARCH IN BUSINESS AND SOCIAL SCIENCES

Vol. 8, No. 7, July 2018, E-ISSN: 2222-6990 @ 2018 HRMARS

$\mathrm{H}$ 2: Past experience has a significant effect on perceived benefits.

H3: Past experience has a significant effect on perceived ease of use.

H4: Perceived benefits have significant effect on online purchase intention.

H5: Perceived ease of use has a significant effect on online purchase intention.

\section{Methodology}

University students gained our highest research interest as they are mostly representatives of the youth customers that are Internet savy and computer literate. In this sense, these skills may become assisting factors that help them navigate shopping websites easily (Aldhmour \& Sarayrah, 2016; Lissitsa \& Kol, 2016). In addition, this group of customers are also motivated by status and peer pressure (Al-maghrabi, Dennis, \& Halliday, 2011). Thus, the unit of analysis of this study is an individual.

A systematic sampling technique was applied to collect the primary data. A pilot study was conducted by the completion of a questionnaire by 100 undergraduate students to test the reliability and validity of the study's design. Then, the data were analysed using SPSS and AMOS 21.0. Subsequently, 400 questionnaires were distributed to the respondents and 280 questionnaires were collected, indicating $70 \%$ response rate. Then, the data were interpreted using analytical tools including SPSS and AMOS 23.0.

\section{Research Framework}

The dependent variable for this study is online purchase intention, whereas the independent variables are past experience, perceived benefits and perceived ease of use. This study aims to investigate the mediating effects of perceived benefits and perceived ease of use on the relationship between past experience and online purchase intention.

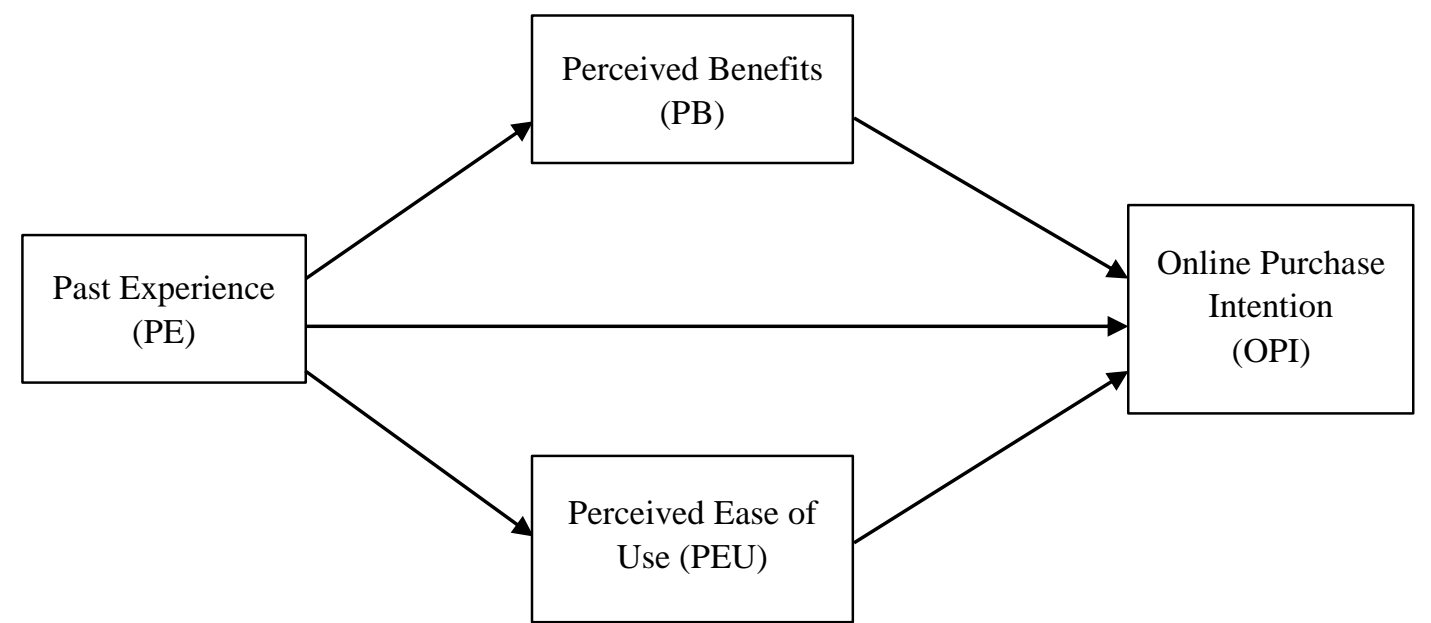

Figure 1: Research Framework

(Adapted from Technology Acceptance Model (Davis, 1989)

This study proposes a conceptual framework for a specific model designed to explain the link between PE, PB and PEU with OPI. The current research lays out a conceptual framework that was designed to analyze the influence of $\mathrm{PB}$ and $\mathrm{PEU}$ on OPI as underpinned by the Technology Acceptance Model (TAM). This study proposes perceived benefits and PEU as mediator variables. Figure 1, which illustrates the essential constructs included in this study, will serve as a guide for 
INTERNATIONAL JOURNAL OF ACADEMIC RESEARCH IN BUSINESS AND SOCIAL SCIENCES Vol. 8, No. 7, July 2018, E-ISSN: 2222-6990 @ 2018 HRMARS

subsequent discussions. In consideration of the literature review, the current research proposes that perceived benefits and PEU would influence the path relationship between PE and OPI among Malaysian youths.

\section{Research Design and Variable Measurement}

The questionnaire consisted of two main sections. The first section of the questionnaire consists of four demographic questions including age, gender, educational level and sources of income. The second section contains multi-items constructs that are measured using a 10-point Likert scale. The constructs in the proposed model were measured using a 23-scale items. PE was measured using 10-points Likert scale anchored from 1 (strongly disagree) to 10 (strongly agree). The measurements were adapted from the validated scales used by Chaudary et al. (2014). The measurements for OPI were adapted from the study done by Topalo (2012) while the measurements for PB and PEU were adapted from Martin et al. (2015) as well as Rose, Clark, Samouel \& Hair (2012).

A survey was designed to test the proposed model. This study chose the survey method because it is best adapted when the aim is to obtain personal and social facts, perception and intention, while also focuses on the merit of enhancing the generalizability of research findings. The relationship of PE and OPI while mediated by PB and PEU was investigated. The 23-items close-ended questions were generated through related empirical studies and literatures. The items were structured in a Likert-type scales ranging from 1 (strongly disagree) to 10 (strongly agree).

\section{Results}

\section{Reliability and Validity of Measurement Items}

For the purpose of analysis and interpretation, exploratory factor analysis was used. The purpose of this study's analysis is to assess the degree of unidimensionality of the scales in the data collected. Commonality among variables is based on the method of Principle Axis Factoring. 23-items were factor analysed. For the verification of the data to be appropriate for the purpose of factor analysis, Kaiser-Meyer-Olkin (KMO) and Bartlett's test were conducted and the results are shown in Table 1 as follows:

Table 1: KMO and Bartlett's Test

\begin{tabular}{|l|l|r|}
\hline \multicolumn{2}{|l|}{ Kaiser-Meyer-Olkin Measure of Sampling Adequacy. } & .865 \\
\hline \multirow{2}{*}{ Bartlett's Test of Sphericity } & Approx. Chi-Square & 1457.324 \\
\cline { 2 - 3 } & $\mathrm{df}$ & 253 \\
\cline { 2 - 3 } & Sig. & .000 \\
\hline
\end{tabular}

Exploratory Factor Analysis was conducted using Principal Axis Factoring and varimax rotation method for data purification. The varimax rotation method was used to produce the matrix that contains the coefficients or loading factors which represent the correlation between the factors and variables. The higher values resulting from $\mathrm{KMO}$ and Bartlett's test proved that the data are appropriate for carrying out factor analysis. Four-factor solutions with a KMO statistic of 0.865 indicates that the sample size was adequate while further Bartlett's test of Sphericity was found significant at .000 and a chi-square statistic of 1457.324 with 253 degrees of freedom. The total 
INTERNATIONAL JOURNAL OF ACADEMIC RESEARCH IN BUSINESS AND SOCIAL SCIENCES Vol. 8, No. 7, July 2018, E-ISSN: 2222-6990 (C) 2018 HRMARS

variance explained by the four factors was 59.148. The results indicate that the data were appropriate for factor analysis.

The items were aggregated resulting to the unearthing of four significant factors. To meet the purpose of the study, these four factors are encoded with new names, which are Factor 1 as Past Experience, Factor 2 as Perceived Benefits, Factor 3 as Perceived Ease of Use and Factor 4 as Online Purchase Intention. A further test of reliability is computed using Cronbach's alpha and the respective reliabilities are reported in the Table 2 . A reliability test of each variable shows alpha values range from .823 to 0.927 which indicate, all items in the scale used to measure the variables in question are reliable. The coefficient Cronbach's Alpha value above 0.6 is considered to be reliable and acceptable. Therefore, we can conclude that the variables in this study pass the reliability test.

Table 2: Results of factor analysis and reliability analysis

\begin{tabular}{|c|c|c|c|c|}
\hline & \multicolumn{4}{|c|}{ Components } \\
\hline & 1 & 2 & 3 & 4 \\
\hline No regrets for having purchased online & .742 & & & \\
\hline Trustworthy experience & .719 & & & \\
\hline Buying online is fun & .654 & & & \\
\hline Never had any bad experience & 619 & & & \\
\hline Very pleased when receiving the goods & .495 & & & \\
\hline Good purchase method & .453 & & & \\
\hline Information & & .801 & & \\
\hline Price comparison & & .799 & & \\
\hline Products comparison & & .782 & & \\
\hline Convenience & & .704 & & \\
\hline Quick decision & & .662 & & \\
\hline Easy to shop & & & .477 & \\
\hline Minimum effort & & & .346 & \\
\hline Easy to use website & & & .346 & \\
\hline Confident & & & .312 & \\
\hline Thinking about shopping online & & & & .811 \\
\hline Expect to purchase online soon & & & & .796 \\
\hline Voluntarily purchase within a month & & & & .791 \\
\hline
\end{tabular}


INTERNATIONAL JOURNAL OF ACADEMIC RESEARCH IN BUSINESS AND SOCIAL SCIENCES Vol. 8, No. 7, July 2018, E-ISSN: 2222-6990 @ 2018 HRMARS

\begin{tabular}{|l|l|l|l|l|}
\hline Daydream about desired items & & & & .671 \\
\hline Probably going to buy online soon & & & & .662 \\
\hline Opportunity & & & & .610 \\
\hline Budget surplus & & & & .491 \\
\hline Consider to buy if price is reasonable & & & & .421 \\
\hline \% of Variance (65.964\%) & 39.390 & 13.243 & 8.326 & 5.006 \\
\hline Eigenvalues & 9.060 & 3.046 & 1.915 & 1.151 \\
\hline Reliability (cronbach's alpha) & 0.821 & 0.899 & 0.814 & 0.900 \\
\hline
\end{tabular}

\section{Confirmation Factor Analysis}

In order to test the various hypotheses, the measurement model was first examined for goodness-of-fit indices and significant factor loadings. The hypothesized measurement model (Figure

2) was

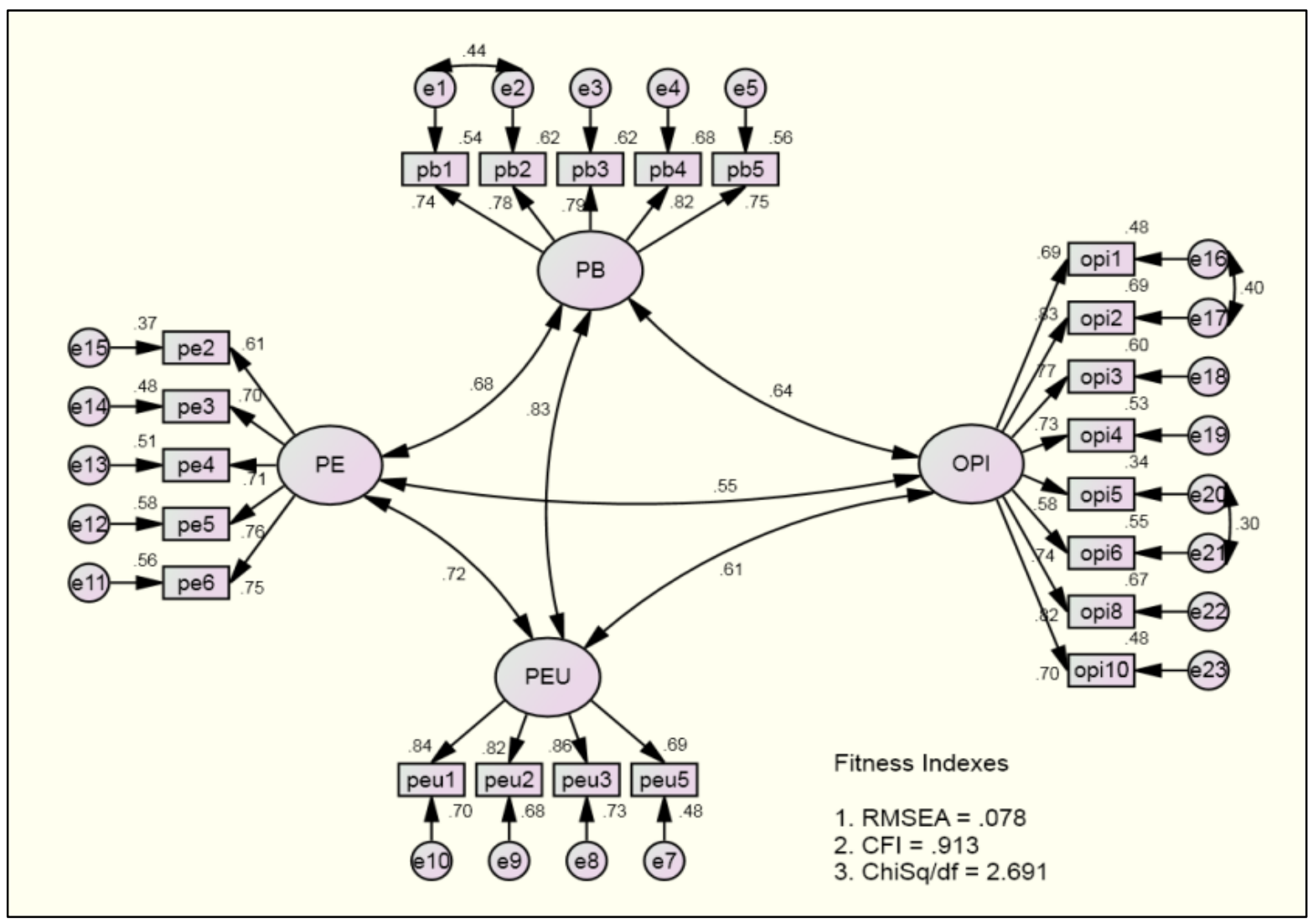

assessed using AMOS.

Figure 2: Factor loading for all items of the respective constructs 
INTERNATIONAL JOURNAL OF ACADEMIC RESEARCH IN BUSINESS AND SOCIAL SCIENCES

Table 3: Goodness-of-fit indices

\begin{tabular}{|l|c|c|c|}
\hline Name of Category & $\begin{array}{c}\text { Goodness-of-fit } \\
\text { Measures }\end{array}$ & Acceptable Value & Index Value \\
\hline Absolute fit & RMSEA & $<0.08$ & 0.078 \\
\hline Incremental fit & CFI & $>0.90$ & 0.913 \\
\hline Parsimonious fit & ChiSq/df & $<3.00$ & 2.691 \\
\hline
\end{tabular}

Table 3 indicates that the goodness-of-fit indices of the proposed model of online purchase intention fit the data reasonably well as confirmed by the RMSEA $=0.078, \mathrm{CFI}=0.913$ and $\mathrm{ChiSq} / \mathrm{df}=$ 2.691.

Table 4: The CFA Report for every construct in the model

\begin{tabular}{|c|c|c|c|c|}
\hline Constructs & Item & Factor Loading & $\begin{array}{c}C R \\
\text { (minimum 0.6) }\end{array}$ & $\begin{array}{c}\text { AVE } \\
\text { (minimum 0.5) }\end{array}$ \\
\hline \multirow[t]{5}{*}{ PE } & pe2 & 0.61 & \multirow[t]{5}{*}{0.833} & \multirow[t]{5}{*}{0.501} \\
\hline & pe3 & 0.70 & & \\
\hline & pe4 & 0.71 & & \\
\hline & pe5 & 0.76 & & \\
\hline & pe6 & 0.75 & & \\
\hline \multirow[t]{5}{*}{ PB } & pb1 & 0.74 & \multirow[t]{5}{*}{0.884} & \multirow[t]{5}{*}{0.603} \\
\hline & pb2 & 0.78 & & \\
\hline & pb3 & 0.79 & & \\
\hline & pb4 & 0.82 & & \\
\hline & pb5 & 0.75 & & \\
\hline \multirow[t]{4}{*}{ PEU } & peu1 & 0.84 & \multirow[t]{4}{*}{0.880} & \multirow[t]{4}{*}{0.648} \\
\hline & peu2 & 0.82 & & \\
\hline & peu3 & 0.86 & & \\
\hline & peu5 & 0.69 & & \\
\hline OPI & opi1 & 0.69 & 0.904 & 0.546 \\
\hline
\end{tabular}


INTERNATIONAL JOURNAL OF ACADEMIC RESEARCH IN BUSINESS AND SOCIAL SCIENCES Vol. 8, No. 7, July 2018, E-ISSN: 2222-6990 @ 2018 HRMARS

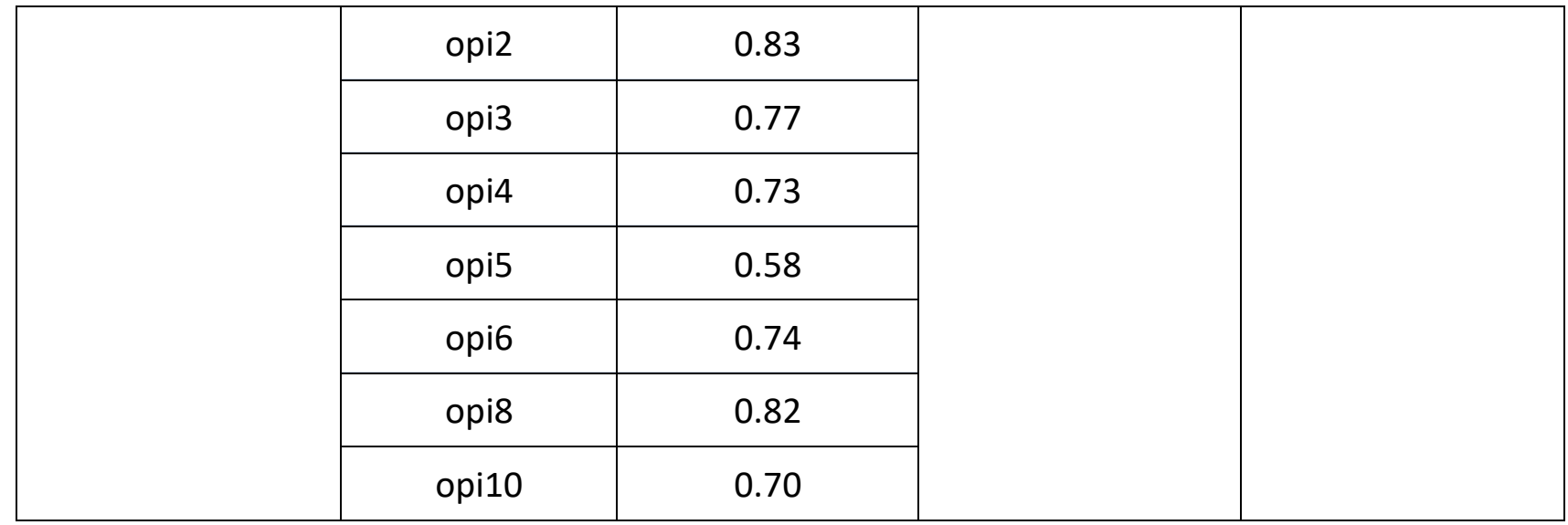

The Composite Reliability (CR) for all factors ranged from 0.880 to 0.904 . The results indicate that the internal consistency was achieved because all CR values are greater than 0.6 (see Table 4). Convergent validity was assessed using Average Variance Extracted (AVE). Convergent validity of items was confirmed by sufficiently large factor loadings ranging from 0.501 to 0.648 . The results indicate that the measurement model was achieved because all values of AVE exceeded 0.50 . Confirmatory factor analyses successfully validated the items used to measure the PE, PB, PEU and OPI.

\section{Structural Equation Modelling}

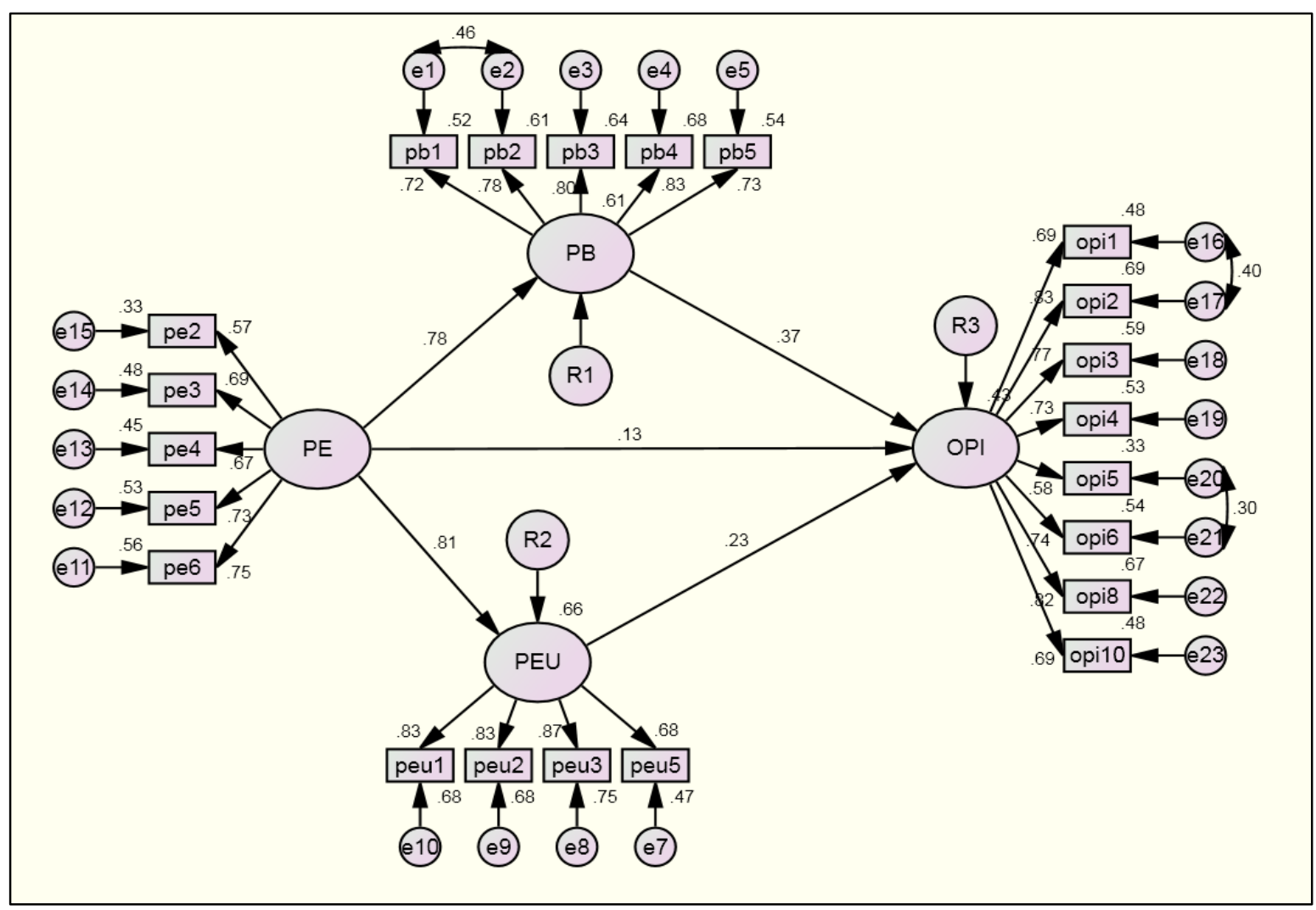

Figure

3: The

Standardized Path Coefficient Between Constructs 
INTERNATIONAL JOURNAL OF ACADEMIC RESEARCH IN BUSINESS AND SOCIAL SCIENCES Vol. 8, No. 7, July 2018, E-ISSN: 2222-6990 @ 2018 HRMARS

Table 5: The Standardized Regression Weights and Its Significance

\begin{tabular}{|lcc|c|c|c|c|c|}
\hline & & & Estimate & S.E. & C.R. & P-value & Results \\
\hline PB & $<--$ & PE & 0.756 & 0.078 & 9.744 & 0.000 & Significant \\
\hline OPI & $<--$ & PB & 0.372 & 0.111 & 3.359 & 0.000 & Significant \\
\hline OPI & $<--$ & PE & 0.124 & 0.157 & 0.786 & 0.432 & Not Significant \\
\hline PEU & $<--$ & PE & 0.854 & 0.076 & 11.173 & 0.000 & Significant \\
\hline OPI & $<--$ & PEU & 0.212 & 0.108 & 1.958 & 0.000 & Significant \\
\hline
\end{tabular}

Notes: $\mathrm{N}=280 ; \mathrm{PE}=$ Past Experience, $\mathrm{PB}=$ Perceived Benefits, $\mathrm{PEU}=$ Perceived Ease of Use, $\mathrm{OPI}=$ Online Purchase Intention

Figure 3 and Table 5 show the regression path coefficients of the measurement model. The results show that there is a significant relationship between PE and PB, PB and OPI, PE and PEU, and $P E U$ and OPI. This indicates that the influence of $P E$ is significantly positive for $P B(\beta=.756, p<.001)$ with an $R^{2}$ value of 0.78 . Besides that, the influence of $P B$ on OPI is also significantly positive with $R^{2}$ value of 0.37 ( $\beta=.372, p<.001)$. Therefore, hypotheses $\mathrm{H} 1$ and $\mathrm{H} 2$ are supported.

The results also show that the influence of PE on PEU is significantly positive with $R^{2}$ value of $0.81(\beta=.854, p<.001)$. Meanwhile, the influence of PEU and OPI is significantly positive with $R^{2}$ value of 0.23 ( $\beta=.212, p<.005)$. Thus, $\mathrm{H} 4$ and $\mathrm{H} 5$ are supported. However, the impact of the PE on OPI is not significant with the $R^{2}$ value of $0.13(\beta=.124, p>.005)$. Hence, H3 is not supported.

\section{Testing the Mediation Effects}

\section{The Results of Mediation Test: Perceived Benefits}

H1: Past experience has a significant effect on online purchase intention.

$\mathrm{H}$ 2: Past experience has a significant effect on perceived benefits.

H4: Perceived benefits have a significant effect on online purchase intention.

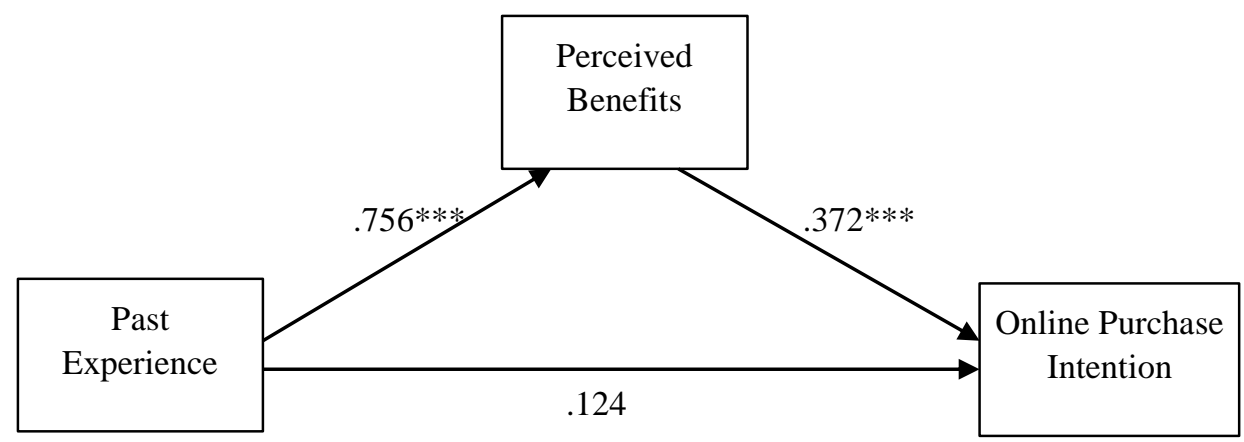

Figure 4: The Standardized Regression Weights for the Model

Table 6: The Results of Mediation Test 
INTERNATIONAL JOURNAL OF ACADEMIC RESEARCH IN BUSINESS AND SOCIAL SCIENCES Vol. 8, No. 7, July 2018, E-ISSN: 2222-6990 @ 2018 HRMARS

\begin{tabular}{|l|c|c|c|}
\hline Hypotheses & Estimate & P-value & $\begin{array}{c}\text { Results on } \\
\text { Hypotheses }\end{array}$ \\
\hline H1: PE has a significant effect on PB & 0.756 & 0.000 & Supported \\
\hline H2: PB have a significant effect on OPI & 0.372 & 0.000 & Supported \\
\hline H4: PE has a significant effect on OPI & 0.124 & 0.432 & Not Supported \\
\hline
\end{tabular}

Notes: $\mathrm{N}=280 ; \mathrm{PE}=$ Past Experience, $\mathrm{PB}=$ Perceived Benefits, $\mathrm{PEU}=$ Perceived Ease of Use, $\mathrm{OPI}=$ Online Purchase Intention

The results of the hypothesis tested in Table 6 indicate that perceived benefit does mediate the relationship between PE and OPI. Thus, the type of mediation here is full mediation since the direct effect is no longer significant after the mediator enters the model.

\section{The Results of Mediation Test: Perceived Ease of Use}

$\mathrm{H} 1$ : Past experience has a significant effect on online purchase intention.

H3: Past experience has a significant effect on perceived ease of use.

H5: Perceived ease of use has a significant effect on online purchase intention.

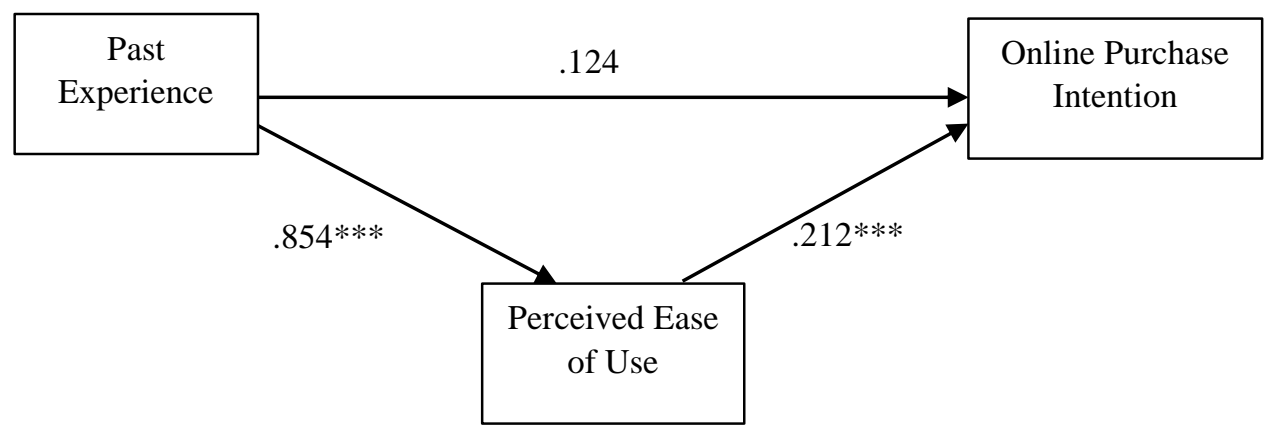

Figure 5: The Standardized Regression Weights for the Model

Table 7: The Results of Mediation Test

\begin{tabular}{|l|c|c|c|}
\hline Hypotheses & Estimate & P-value & $\begin{array}{c}\text { Results on } \\
\text { Hypotheses }\end{array}$ \\
\hline H1: PE has a significant effect on OPI & 0.124 & 0.432 & Not Supported \\
\hline H3: PE has a significant effect on PEU. & 0.854 & 0.000 & Supported \\
\hline H5: PEU has a significant effect on OPI & 0.212 & 0.000 & Supported \\
\hline
\end{tabular}


INTERNATIONAL JOURNAL OF ACADEMIC RESEARCH IN BUSINESS AND SOCIAL SCIENCES Vol. 8, No. 7, July 2018, E-ISSN: 2222-6990 @ 2018 HRMARS

Notes: $\mathrm{N}=280 ; \mathrm{PE}=$ Past Experience, $\mathrm{PB}=$ Perceived Benefits, $\mathrm{PEU}=$ Perceived Ease of Use, $\mathrm{OPI}=$ Online Purchase Intention

The results of the hypothesis tested in Table 7 indicate that PEU does mediate the relationship between PE and OPI. Thus, the type of mediation here is full mediation since the direct effect is no longer significant after the mediator enters the model.

\section{Discussions and Implications}

The current findings indicate that both PB and PEU have positive relationship with OPI. These findings are consistent with those by previous researchers such as Al-Debei et al. (2015), Lim et al. (2016), Salehi et al.(2011), Sheikh et al. (2015). Our findings show that indeed the PB and PEU are important in affecting the consumer's intention to purchase. Moreover, it is PB and PEU that are affected by PE; thus, a dynamic view of both perceptions in which it changes with the consumer's experience is likely to be a substantial factor in determining the OPI. The results indicate that past purchasing experience may affect consumers' perception of benefits and ease of use, which in turn may influence their intention to purchase online. In other words, if consumer's perceived benefits and ease of use on their past purchasing experience are positive, then these will positively influence their intention to repurchase in the future.

PE is proved to have a positive relationship with PB and PEU. Previously, researchers including Chaudary et al. (2014), Nwaizugbo \& Ifeanyichukwu (2016), Weisberg et al. (2011) have proven that PE has a significant relationship with OPI. A consumer who has tried to shop online once and enjoyed the entire process may continue to repurchase online in the future. It implies that the more positive the consumers' experience with online transactions in the past, the higher the likelihood for them to repurchase (Nwaizugbo \& Ifeanyichukwu, 2016).

However, the current study found that the direct effect of PE on OPI is no longer significant after the mediators enter the model. These results contradict with some of the findings in previous studies which found that past purchasing experience on the Internet has a substantial impact on the intention to purchase (Chaudary et al., 2014; Salehi et al., 2011; Weisberg et al., 2011). Meanwhile, Martin et al. (2015) supported the claim that PB and PEU of navigational aids may influence intention to repurchase. Therefore, we can conclude that PB and PEU work together in enhancing the OPI among university students in Malaysia.

Nevertheless, these results could also be explained by the fact that online retailers should design marketing strategy wisely to captivate customers who are more experienced in online shopping. A probable reason is high-experience customers are more rational in their decision-making compared to the less-experienced ones (Pappas, Pateli, Giannakos \& Chrissikopoulos, 2014).

Therefore, online retailers need to reach positive online customer experience by engaging them with a credible web page in various interactive ways as well as focusing on involvement, concentration and enjoyment. The web page design, navigation and information searching convenience as well as security warranty play vital roles in attracting and retaining online customers (Nuryakin \& Farida, 2016).

The results of this research have important implications for online retailers and business practitioners. They are expected to assist online retailers to enhance their business strategy to remain competitive and relevant in the virtual business environment. This paper provides valuable information for online retailers who are interested in exploring the developing market among 
INTERNATIONAL JOURNAL OF ACADEMIC RESEARCH IN BUSINESS AND SOCIAL SCIENCES

Vol. 8, No. 7, July 2018, E-ISSN: 2222-6990 @ 2018 HRMARS

university students in Malaysia. Kumar (2016) puts forth that online retailers should maximize their efforts in reinforcing their relationship with the customers.

\section{Conclusion}

The full mediating effect of PB and PEU on the path relationship between PE and OPI is the main contribution of this study. The effect of past purchases on future purchases cannot be understood by neglecting the concurrent effect on PB and PEU because changes in the latter will affect OPI. This study has a few limitations. First, it did not consider the income or socio-economic status of the subjects for the model. Before making any decisions on online shopping, a customer may do a cost-benefit analysis. Notably, this study was only carried out among university students who are mostly dependent on an educational loan from the same source, namely The National Higher Education Fund (Perbadangan Tabung Pendidikan Tinggi Nasional). However, there may be some students who received extra funding in the form of pocket money from their parents. Thus, the costbenefit analysis may differ between the group of students who only depend on educational loan and the group of students who received extra pocket money from their parents. Therefore, we suggest that future studies should consider testing out the moderating effect of socio-economics status which can probably provide different results that are highly sought after and thus contribute to a deeper understanding of consumer behaviour towards online shopping.

Furthermore, this study was carried out only among students in a higher learning institution in the State of Pahang, Malaysia. Hence, the results may not be fully generalized for all university students in other parts of Malaysia. We also suggest that future researchers to include more variables of consumer behaviour to see their effects on online purchase intention. The use of past experience as a moderator variable may gain more fruitful findings.

\section{Corresponding Author:}

Nurul Nadia Abd Aziz

Faculty of Business and Management, Universiti Teknologi MARA Cawangan Pahang Kampus Raub, 27600 Raub, Pahang, Malaysia

Email: nurul_nadia@pahang.uitm.edu.my

\section{References}

Al-Debei, M. M., Akroush, M. N., \& Ashouri, M. I. (2015). Consumer attitudes towards online shopping: The effects of trust, perceived benefits, and perceived web quality. Internet Research, 25(5), 707-733.

Al-maghrabi, T., Dennis, C., \& Halliday, S. V. (2011). Antecedents of continuance intentions towards e-shopping : the case of Saudi Arabia. Journal of Enterprise Information Management, 24(1), 85111.

Aldhmour, F., \& Sarayrah, I. (2016). An investigation of factors influencing consumers' intention to use online shopping: An empirical study in South of Jordan. Journal of Internet Banking and Commerce, 21(2), 1-48.

Alomary, A., \& Woollard, J. (2015). How is technology accepted by users? A review of technology acceptance models and theories. In Proceedings of The IRES 17th International Conference (pp. 1-4).

Aziz, N. N. A., \& Wahid, N. A. (2017). Understanding customer behaviour towards online shopping. In 2nd Business Management and Computing Research Colloquium (pp. 164-168). 
INTERNATIONAL JOURNAL OF ACADEMIC RESEARCH IN BUSINESS AND SOCIAL SCIENCES

Vol. 8, No. 7, July 2018, E-ISSN: 2222-6990 @ 2018 HRMARS

Chakraborty, R., Lee, J., Bagchi-Sen, S., Upadhyaya, S., \& Raghav Rao, H. (2016). Online shopping intention in the context of data breach in online retail stores: An examination of older and younger adults. Decision Support Systems, 83, 47-56.

Chaudary, M. W. T., Ahmed, F., Gill, M. S., \& Rizwan, M. (2014). The determinants of purchase intention of consumers towards counterfeit shoes in Pakistan. Journal of Public Administration and Governance, 4(3), 20. http://doi.org/10.5296/jpag.v4i3.5847

Davis, F. (1989). Perceived usefulness, perceived ease of use, and user acceptance of information technology. MIS Quarterly, 13, 319-340.

Dhanapal, S., Vashu, D., \& Subramaniam, T. (2015). Perceptions on the challenges of online purchasing: A study from "baby boomers", generation " $X$ " and generation " $Y$ " point of views. Contaduria Y Administracion, 60, 107-132.

Durodolu, O. O. (2016). Technology Acceptance Model as a predictor of using information system ' to acquire information literacy skills. Library Philosophy and Practice, (November), 1-27.

Faqih, K. M. S. (2016). An empirical analysis of factors predicting the behavioral intention to adopt Internet shopping technology among non-shoppers in a developing country context: Does gender matter? Journal of Retailing and Consumer Services, 30, 140-164.

Gianina, A., \& Lala, F. (2014). Innovation and technology acceptance model (TAM): A theoretical approach. Romanian Journal of Marketing, 59-66.

Gong, W., Stump, R. L., \& Maddox, L. M. (2013). Factors influencing consumers' online shopping in China. Journal of Asia Business Studies, 7(3), 214-230.

Ha, H.-Y., \& Janda, S. (2014). The effect of customized information on online purchase intentions. Internet Research, 24(4), 496-519.

Handa, M., \& Gupta, N. (2014). A study of the relationship between shopping orientation and online shopping behavior among Indian youth. Journal of Internet Commerce, 13(1), 22-44.

Hernandez-Ortega, B., Jimenez-Martinez, J., \& Martin-DeHoyos, M. J. (2008). Purchasing behaviour Differences between potential, new and experienced e-customers Analysis of e-purchasing behaviour. Internet Research, 18(3), 248-265.

Huseynov, F., \& Yildirim, S. O. (2016). Internet users' attitudes toward business-to-consumer online shopping : A survey. Information Development, 32(3), 452-465.

Jaafar, S. N., Lalp, P. E., \& Mohamed, M. (2013). Consumers' perceptions, attitudes and purchase intention towards private label food products in Malaysia. Asian Journal of Business and Management Sciences, 2(8), 73-90.

Jadhav, V., \& Khanna, M. (2016). Factors influencing online buying behavior of college students : a qualitative analysis factors influencing online buying behavior of college students : A, 21(1), 115.

Kumar, M. (2016). Consumer behavior and satisfaction in e-commerce: a comparative study based on online shopping of some electronic gadgets, 7, 62-67.

Leung, X. Y., Bai, B., \& Stahura, K. a. (2015). The marketing effectiveness of social media in the hotel industry: a comparison of Facebook and twitter. Journal of Hospitality \& Tourism Research, $37(2), 1-24$.

Lian, J.-W., \& Yen, D. C. (2014). Online shopping drivers and barriers for older adults: Age and gender differences. Computers in Human Behavior, 37, 133-143. http://doi.org/10.1016/j.chb.2014.04.028

Lim, Y. J., Osman, A., Salahuddin, S. N., Romle, A. R., \& Abdullah, S. (2016). Factors influencing online shopping behavior: the mediating role of purchase intention. Procedia Economics and Finance, 
INTERNATIONAL JOURNAL OF ACADEMIC RESEARCH IN BUSINESS AND SOCIAL SCIENCES

Vol. 8, No. 7, July 2018, E-ISSN: 2222-6990 @ 2018 HRMARS

35(October 2015), 401-410.

Lissitsa, S., \& Kol, O. (2016). Generation X vs. Generation Y - A decade of online shopping. Journal of Retailing and Consumer Services, 31, 304-312.

Martin, J., Mortimer, G., \& Andrews, L. (2015). Re-examining online customer experience to include purchase fre- quency and perceived risk. Journal of Retailing and Consumer Services, 25, 81-95.

Massad, V. J., \& Berardelli, K. (2016). The roles of bounded rationality and ethical self-efficacy in online shopping orientation. Academy of Marketing Studies Journal, 20(3), 26-37.

Nuryakin, \& Farida, N. (2016). Effects of convenience online shopping and satisfaction on repeatpurchase intention among students of higher institutions in Indonesia. Journal of Internet Banking and Commerce, 21(2).

Nwaizugbo, I. C., \& Ifeanyichukwu, C. D. (2016). Understanding consumers' behaviour towards online shopping: A study of online shoppers in Anambra State. International Journal of Sales, Retailing and Marketing, 5(2), 28-38.

Pantano, E., \& Viassone, M. (2015). Engaging consumers on new integrated multichannel retail settings: Challenges for retailers. Journal of Retailing and Consumer Services, 25, 106-114.

Pappas, I. O., Pateli, A. G., Giannakos, M. N., \& Chrissikopoulos, V. (2014). Moderating effects of online shopping experience on customer satisfaction and repurchase intentions. International Journal of Retail \& Distribution Management, 42(3), 187-204.

Rose, S., Clark, M., Samouel, P., \& Hair, N. (2012). Online customer experience in e-retailing: an empirical model of antecedents and outcomes. Journal of Retailing, 88(2), 308-322.

Saidi, N. (2016, May). Bijak belanja pada musim perayaan. Utusan Online.

Salehi, M., Nwaizugbo, I. C., \& Ifeanyichukwu, C. D. (2011). Consumer buying behavior towards online shopping stores in Malaysia. International Journal of Academic Research in Accounting, Finance and Management Sciences, 1(2), 10.

Sheikh, J. A., Abbas, A., \& Mehmood, Z. (2015). Design consideration of online shopping website to reach women in Pakistan. Procedia Manufacturing, 3(Ahfe), 6298-6304.

Surendran, P. (2012). Technology Acceptance Model : A Survey of Literature. International Journal of Business and Social Research, 2(4), 175-178.

Topalo, C. (2012). Consumer motivation and concern factors for online shopping in Turkey. Asian Academy of Management Journal, 17(2), 1-19.

Weisberg, J., Te'eni, D., \& Arman, L. (2011). Past purchase and intention to purchase in e-commerce: The mediation of social presence and trust. Internet Research, 21(1), 82-96. 